\title{
Exploring pedagogical competence in a distance education nursing program: A case study
}

\begin{abstract}
Anna Vioral
The West Penn Allegheny Health System, Pittsburgh, Pennsylvania, USA, and School of Nursing, Duquesne University, USA
\end{abstract}

Correspondence: Anna Vioral. Address: 185 Lager Drive, Gibsonia, Pennsylvania, USA. Email: avioral@wpahs.org.

Received: May 29, 2012

DOI : $10.5430 /$ jnep.v3n9p36

Accepted: January 9, 2013

Online Published: February 25, 2013

\section{Abstract}

The proliferation of distance education programs and online learning presents tremendous opportunities to expand nursing educational offerings. The emergence of online learning into nursing education has also resulted in significant changes in pedagogy and institutional leadership. This case study investigates how leaders address pedagogical competence in a nursing program offering distant education courses according to selected national standards. This case study utilizes a triangulation assessment to address two research questions describing the experiences of a nursing program offering online courses. The Contingency Leadership Theory provides the theoretical framework. Data collection methods include a pre-interview assessment survey, telephone interviews of key respondents, and review of additional evidence.

The results of this investigation reveal themes derived from data collection including technological environment, pedagogy, and leadership. The findings of this study may assist nursing leadership in their efforts to address pedagogical competence and to provide technological resources as nursing programs design or redesign their online education. Future research suggestions include exploring how pedagogical instructional design skills can be integrated into the course development process and examining the possible connections between pedagogical competence and program outcomes.

\section{Key words}

Contingency theory, Distance education, Environment, Leadership, Pedagogical competence, Pedagogy, Technology

\section{Introduction}

The worldwide nursing and faculty shortage has led nursing programs to recognize the need for creative strategies to meet the shortage needs. Rapid solutions to address the nursing shortage include the development of online learning opportunities ${ }^{[1]}$. These solutions include the hiring of nursing faculty based on the need rather than on pedagogical preparation and competence ${ }^{[1]}$; preparing nurse educators with minimal instructional technology preparation ${ }^{[2]}$; and lacking higher education established national teaching requisites ${ }^{[3]}$.

The integration of technologies into a distant teaching and learning process reflects a shift that educators have used for many years from the traditional "teaching" paradigm to facilitating learning transactions with physical separation and technological requirements ${ }^{[4]}$. Faculty must learn new pedagogical roles to develop and implement courses including technologies for enhancing teaching, instructional design, and course management ${ }^{[5]}$. Nurse educators making this shift 
often have no experience in the development or teaching of online courses and struggle with the role changes required in distance education ${ }^{[6]}$. Therefore, faculty members have to acquire specialized skills and pedagogical competence in instructional technology and design to ensure successful outcomes.

No theoretical definition for pedagogical competence is identified in the literature. Common defining attributes across the literature defines pedagogical competence as the knowledge, skills, experiences, ability, aptitude, and attitudes necessary to carry out a defined function effectively ${ }^{[7]}$. Based on the defining attributes, pedagogical competence is operationally defined as the ability to perform in the nursing academic context (online education) by applying the knowledge, skills, and experience of the pedagogical principles in curriculum development, instructional strategies, use of instructional technology, and evaluation techniques as outlined in the National League of Nursing (NLN) Nurse Educator Core Competencies ${ }^{[8]}$. Technology encompasses the internet, electronic mail, learning management systems, multimedia applications, and databases to name a few ${ }^{[9]}$. Instructional technology promotes student learning by bridging the gap between the technology and how students learn ${ }^{[10]}$. Instructional design consists of systematic instructional planning including needs assessment and the development, evaluation, implementation, and maintenance of materials and programs $^{[11]}$. Thus, the essential components to online education involve online pedagogical skills using instructional technology to plan, design, develop, deliver, evaluate, and manage the online programs.

Unfortunately, leadership often assigns a variety of meanings to what constitutes pedagogical skills for online teaching and learning ${ }^{[12]}$. The meanings vary from institution to institution and knowledge of the specifics related to online pedagogical skills remains predominately within the confines of individual institutions. Little knowledge exists about how leaders in distance education nursing programs ensure the faculty has the pedagogical skills to teach online. The lack of research involving the intricate conceptual triad of leadership, pedagogical competence, and the technological teaching/ learning environment upholds the significance of this case study research.

The purpose of this case study was to describe how a nursing program delivering online education was meeting the NLN Nurse Educator Core Competencies and the International Association for K-12 Online Learning (iNACOL) National Standards of Quality for Online Courses. The study investigated how leaders addressed pedagogical competence in distance education nursing programs according to selected national standards. This case study addressed two research questions: 1) How are leaders in a distance education nursing program ensuring the faculty have the pedagogical skills necessary to teach online? 2) How is a nursing program addressing pedagogical competence in distance education nursing programs according to the selected standards set forth by the NLN Core Competencies for Nurse Educators and iNACOL National Standards of Quality for Online Courses?

\subsection{Review of literature}

Studies identified that faculty members require exposure to the various pedagogical strategies best suited for the distance education environment ${ }^{[13,14]}$. Innovative online instruction extended beyond uploading traditional lectures and handouts to the web. Formatting the information in an interactive and inventive manner to enhance the teaching and learning process should prevail ${ }^{[15]}$. However, inadequate training and support services for online faculty repeatedly emerged in literature as two of the foremost issues identified by full-time faculty as barriers to offering online courses ${ }^{[16]}$ with few programs adequately preparing faculty in pedagogical principles of curriculum, instruction, technology, and evaluation ${ }^{[17]}$. Johnson ${ }^{[18]}$ reported that nurse educators making the transition to teaching online often had no experience in the development or teaching of online courses; thus, even seasoned faculty found themselves in a position of a novice educator.

Efforts have been made to reform teacher preparation by the National Council for the Accreditation of Teacher Education ${ }^{[19]}$, the American Association of Colleges of Nursing ${ }^{[20]}$, the National League for Nursing ${ }^{[8]}$, the Institutes of Medicine ${ }^{[21]}$, and the International Association for K-12 Online Learning ${ }^{[22]}$ to provide recommendations and guidelines on how to incorporate instructional technology competencies into nursing education. However, knowledge and skills 
required to design and teach online have often been taken for granted or assumed by administrators as basic faculty member skills ${ }^{[23]}$. Institutions must develop appropriate infrastructure and training prior to offering online learning opportunities. A skilled faculty with pedagogical competence of online instruction and administrative support promotes a successful online educational experience ${ }^{[24]}$.

Although many universities and nursing programs have been offering online education for years, Allen and Seaman ${ }^{\text {[25] }}$ reported that most academic leaders continue to take a neutral stance regarding concerns related to current processes for providing administrative support services for faculty. According to Meyer ${ }^{[26]}$ and Runyon ${ }^{[27]}$, when an institution increased instructional duties for online faculty, additional administrative support services arose such as: providing technical support, establishing faculty development opportunities, and mentoring for online faculty. Meyer ${ }^{[26]}$ suggested that well-planned administrative support services by distance education coordinators had a positive influence on both instructional practices and student learning outcomes. When distance education coordinators did not fully understand the administrative support needs of their online faculty, their colleges faced higher faculty turnover and lower quality online education ${ }^{[27]}$. Distance education administrators responsible for the advancement and quality of online instruction need to improve their grasp of the specific administrative support service needs of online faculty.

Clearly, the complexity of pedagogical competence, technology, and leadership in distance education nursing programs demands further research. Literature does not provide evidence as to how nursing programs offering online courses address pedagogical competence according to selected national standards or how administrative leaders contribute to faculty development and support. Therefore, understanding how and to what extent pedagogical competencies are being integrated into the online classroom with administrative support contributes significantly to the scholarly literature.

\subsection{Theoretical framework}

The Contingency Leadership Theory provides the theoretical framework for this case study. This theory focuses on the relationship between an organization and the environment ${ }^{[28]}$. The earliest and most extensively researched contingency theory dates back to Fiedler ${ }^{[28]}$ who departed from the behavioral models and asserted that group performance is contingent on three variables: group atmosphere, task structure, and leader's power position ${ }^{[29]}$. The contingency theory posits that effective patterns of organizational structure and behavior are contingent on environmental and task demands ${ }^{[30]}$. Changes in an environment require appropriate changes in patterns of the organization to deal with that environment ${ }^{[30]}$. Success depends on the number of variables, including the leadership style, qualities of the followers, and aspects of the situation. Figure 1 illustrates a schematic diagram of the contingency theory. This case study research upholds that successful distant education nursing programs are contingent on three variables: technological environment, pedagogical competence, and leadership. Leaders of nursing programs offering online courses should: secure infrastructure with online policies and standards, establish technological resources and support, and prepare faculty in pedagogical principles. Favorable outcomes for nursing programs offering online courses are contingent upon, technology, pedagogical competence, and leadership in a collaborative model. Therefore, this case study applies the contingency theoretical framework to link the technology learning environment, pedagogical competence, and leadership in the exploration of a distant education nursing program.

\section{Methodology}

A case study research design provided the framework for this the study. According to Yin ${ }^{[31]}$, using a case study design allowed the researcher to conduct the study and analysis simultaneously. This methodology was useful for describing an intervention and the real-life context in which it occurred ${ }^{[31]}$ with a detailed contextual analysis as a basis for application of the ideas and extension of the methods to the nursing literature. This case study provided an in-depth analysis of the complex issue of pedagogical competence in distance education nursing programs. Furthermore, the design enabled the researcher to fully examine various data sources to present a richer picture of the phenomena. The research design used a 
combination of methodologies for increased validity of the study by constructing a case study protocol. The study described the experiences of a nursing program offering online courses.

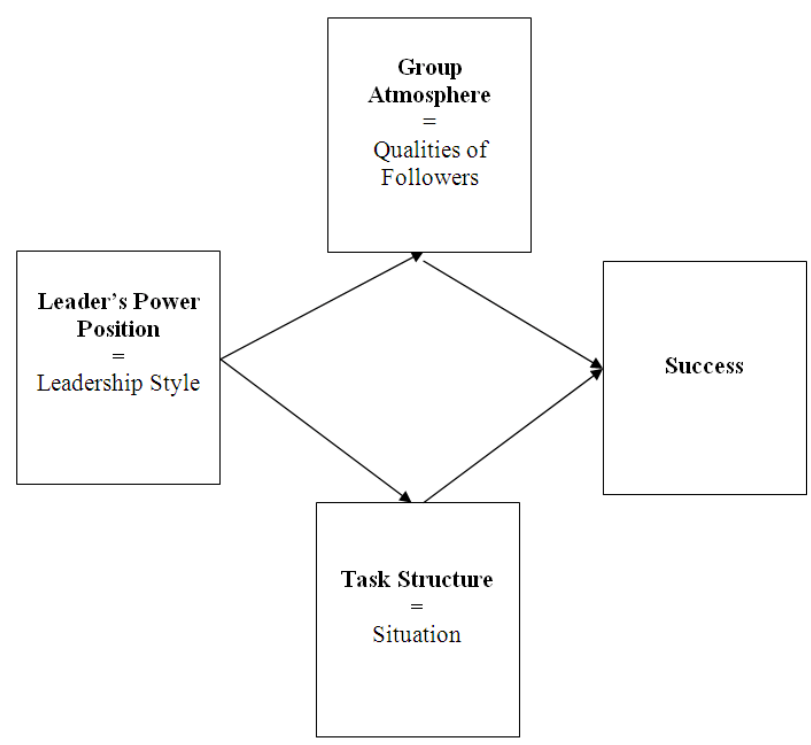

Figure 1. Contingency Theory

\subsection{Participants}

After Institutional Review Board (IRB) approval, a purposive sample using a unit of analysis consisting of nursing programs in the United States who were awarded the NLN Center of Excellence Award was selected. Inclusion criteria were nursing programs that offered online education in BSN, MSN, PHD, and/or DNP programs, and had been awarded the NLN Center of Excellence award twice in the past decade $(\mathrm{N}=3)$. The researcher was seeking up to three nursing program administrators and three faculty members who had taught in at least one online course in the selected nursing program within the last year.

\subsection{Instruments}

Three instruments were utilized in this case study.

1) The Nursing Administrator Self-Assessment Survey of Quality for Online Courses was a pre-interview survey tool for administrators. Eight demographic characteristics were collected in part one of the survey. Part two of the survey used selected standards of practice from the Core Competencies of Nurse Educators with Task Statements published by the NLN ${ }^{[8]}$ including: curriculum design and evaluation of program outcomes; functioning as change agent and leader; and functioning within the educational environment. Part three of the survey used selected performance standards from the iNACOL National Standards of Quality for Online Courses: content, instructional design, student assessment, technology, and course evaluation and management ${ }^{[22]}$. Each domain encompassed a subscale addressing competencies within the domain.

2) The Nursing Faculty Self-Assessment Survey of Quality for Online Courses was a pre-interview survey tool for faculty members. Eight demographic characteristics were collected in part one of the survey. Part two of the survey used selected standards of practice from the Core Competencies of Nurse Educators with Task Statements published by the $\mathrm{NLN}^{[8]}$ including: facilitating learning; facilitating learner development and socializations; and using assessment and evaluation strategies. Part three of the survey used selected performance standards from the iNACOL National Standards of Quality for Online Courses: content, instructional design, student assessment, 
technology, and course evaluation and management ${ }^{[22]}$. Each domain encompassed a subscale addressing competencies within the domain. Both instruments were chosen for this case study because the competency statements in each overlap thereby increasing the reliability and validity of the survey tool.

3) Audio-taped interviews used an Interview Guide to explore administrator and faculty perceptions about online programs such as: defining instructional design; describing nursing faculty requirements to develop online courses; discussing training provided for online courses; clarifying any performance rating below a " 3 ” on the pre-interview survey; and providing examples of how the NLN and iNACOL standards were integrated into their programs.

\subsection{Data collection procedures}

A mailing was sent to the Dean from each eligible program to assess interest in participating in the study and then forwarded to all eligible faculty members by the Dean. The first administrator $(n=1)$ and faculty member $(n=1)$ that replied was selected for this case study. The researcher was unable to obtain further participants due to the time constraints for the study. Consents were completed electronically. Each tool was identified as "F" for the faculty member and "A" for the administrator to protect identity, and the participants could have withdrawn at any time.

Each participant was e-mailed a pre-interview assessment survey to rate the performance statements integrated into their online program using a scale from 0 (being absent) to 4 (needing no improvement). They were given one week to complete the survey. The follow-up 30-60 minute audio-taped interview was conducted after the participants returned the completed survey. A variety of additional data collection assessments contributed to a more comprehensive case study and increased the study validity through triangulation including:

- Observing an online course taught by the interviewed faculty member to assess the course syllabi, the Learning Management System (LMS), discussion forums, course assignments, course rubrics, and course evaluations.

- Examining programmatic objectives, CCNE accreditation self-study report, department policies, university and department mission and vision, strategic plans, faculty curriculum vitae, and the NLN Center of Excellence application.

The additional data collection occurred simultaneously while the participants were completing the survey and interviews.

\subsection{Data analysis and findings}

The researcher used an inductive process to gather data, sort, and analyze a chain of evidence for the case study database. Collecting multiple sources of evidence encourages converging lines of inquiry ${ }^{[31]}$. The researcher maintained a systematic and comprehensive analytical process to exhaust the data sources related to the phenomena. The audio-taped interviews were transcribed by a professional transcriptionist and provided qualitative data to validate the quantitative results. The researcher validated the integrity of the transcribed documents by identifying key words and phrases. Tentative categories and themes were then extracted. The researcher used an inductive analysis process with patternmatching logic to compare the data with the idealized theoretic patterns to increase the study's internal validity ${ }^{[31]}$. The researcher then organized the data into categories with related themes describing how leaders ensure faculty have pedagogical skills to teach online and how their program addressed pedagogical competence according to selected national standards.

\subsubsection{Demographic data}

The participants in the case study were recruited from a large university in the central region of the United States. The program offered online nursing courses for over 15 years. The participants' were Caucasian females between the ages of 48-57. The administrator had more than 25 years' experience teaching with 11-15 years online. The faculty member had 
6-10 years' experience teaching with less than 5 years online. Both had taught in BSN, RN-to-BSN, MSN, DNP and PhD courses.

\subsubsection{Themes}

Three overarching categorical themes emerged from the analysis: environment, pedagogy, and leadership along with related sub-themes. Table 1 shows the relationships between the interview questions, themes, and sub-themes.

Table 1. Selected Themes and Sub-Themes

\begin{tabular}{lll}
\hline Guided Interview Question & Theme & Sub-Themes \\
\hline $\begin{array}{l}\text { 1. Define instructional design and its components. } \\
\text { Lechnological Environment Styles Communication } \\
\text { Inter-activity } \\
\text { Support/Resources } \\
\text { Tevelopment of online courses in your institution }\end{array}$ & $\begin{array}{l}\text { Technology } \\
\text { 3. Discuss the training provided to the nursing faculty for online } \\
\text { course development and implementation at your institution. }\end{array}$ & Support/ Resources Competence \\
$\begin{array}{l}\text { 4. Provide specific examples of how our school integrates the } \\
\text { NLN and iNACOL standards into your online courses. }\end{array}$ & Leadership & Experience \\
\hline
\end{tabular}

Environment. When asked to define instructional design and its components in regards to online learning, neither participant provided a clear definition of instructional design. Both participants did identify the importance of the learning environment in distant education particularly addressing learning styles, communication, inter-activity, resources, and technology.

F: "One must know that people learn in different ways and in four big ways: visual, kinesthetic, auditory, and orally. I try very hard to incorporate something from each of those areas in the online environment”

A: "Faculty must maximize attending to different learning styles that students will bring to the experience. Capturing this in the online environment requires communication between and amongst students and between the faculty and student, and giving the students resources in each of the learning domains"

The administrator focused on the necessity of ongoing communication and interactivity that is required in online learning:

A: "When you design the online learning experiences maximizing inter-activity and fostering communication, then students do not feel isolated in the online course. You will hear students sometimes say that they feel like they are doing it in isolation which is a big concern that affects satisfaction......with the added technological pedagogical component faculty often question, how am I going to utilize this technology so it does not create barriers to learning, but instead facilitates it”?

The administrator also expressed the need for resources and technology in the online environment:

A: "The ease of navigation, how this is actually structured, set-up, and designed in the first place, which many faculty do not have that expertise. It takes a little assistance from an expert about how to design and set up the navigation of the course so that the focus is on teaching and learning and not the technology."

Pedagogy. Participants were asked to describe how prepared faculty members felt they were to teach online. Participants agreed on the importance of training, support, and resources required to teach online: 
A: "I think that when you make the transition from the classroom to the online environment there is a tendency to sometimes take what they have done in a classroom and just dump it into the online environment thinking that will work, and no, there has to be a reshaping after the instructional design, and faculty has to have some assistance in terms of how to organize and shape that content to assure the learner is getting what is needed".

F: "I think you really do have to know what you are doing and I think you have to know who you are as a teacher before you make that leap. I think it is complicated and I think there are a lot of things to be thought about and I think a lot of people have not thought about them"

However, the audio-interviews revealed that no specific nursing faculty requirements existed for online learning or for the faculty members to develop or to teach online courses in the nursing program. Despite the lack of formalized training and development, the participants discussed the significant amount of resources available for online course development and design, and support with the LMS.

A: "We are very fortunate to have an instructional designer right here on our faculty in the School of Nursing who runs all sorts of workshops throughout the year based upon what is heard from faculty, what they need, and what experience may be helpful. The University and campuses have centers for teaching and learning with expertise in terms of how to engage in best practices and development of online courses, so our faculty has access to resources in the school and on campus. You name it, we cover it, and so we are very, very fortunate. None of our faculty should ever say they were not able to access the support needed to develop and learn to teach online”.

F: "There are a lot of offerings through the department and a dedicated person for the learning management system. The administrative support and resources are very well versed in the basics and the resources and opportunities are there to get good help....when I taught at previous schools there was little to no support”.

The program offers additional resources related to pedagogical development such as: 'web-based' peer review assessment tool and a faculty development series. The course materials were reviewed and do not merely mimic the classroom materials placed in an online environment. The assignments, discussion forums, and content design illustrate online pedagogical competence measured by the national standards. Student end-of-course evaluations were also reviewed. Aggregate feedback revealed that $92 \%$ of the students were very satisfied with the online experience, teaching strategies, and rated the instructor highly effective in teaching online. The remaining $8 \%$ reported being satisfied with the course and instructor. No student reported dissatisfaction with the course or instructor.

Leadership. During the interviews, participants expressed the importance of collaboration with leadership on pedagogy and the online environment. Both participants described that online teaching and learning required strong infrastructure with administrative support and resources for the online environment when teaching online. Both participants were asked to provide specific example(s) on how the leaders of the school integrate NLN Nurse Educator Core Competencies and the iNACOL National Standards in the online nursing program. The participants commented that the NLN and iNACOL competencies were not developed with online learning in mind:

A: "Reading those individually I think our faculty as a whole do very, very well with addressing the competencies in either one of those models. This framework that you are using has not been consciously fostered here in our curriculum. They can certainly be applied to online learning but in my mind is not different than applying them to the program at large. Online learning is not separate; it is very much embedded into our normal curriculum discussion so I cannot separate those two as well in my mind".

F: "Although the competencies were not specifically developed for online learner, they can be applied to the online learning environment”. 
Again, the amount of resources necessary for an online program was discussed by both participants:

A: "Online is not easier, online is not cheaper, it takes a lot of inner support and administration has to understand that when they ask faculty to teach online. I am very well supported and I have acquired a lot of resources”.

F: "The workload is more intense but I have administrative support...they have the resources to help me...someone is always there to help me...the administrative support are very competent in what they do...they have a lot of rich resources".

Additional documents and programs were reviewed including the peer review 'web-based' course assessment tool used by those faculty seeking promotion and tenure, the nursing program strategic plan, CCNE self-study report, University and School of Nursing Mission and vision, and the NLN Center of Excellence application. Impressively, $67 \%$ of the faculty earned doctorate degrees in nursing education and $46 \%$ of the faculty hold the Certification as a Nurse Educator (CNE). These documents, the faculty development series, and the Center for Teaching and Learning validate the internal program congruency to inspire learning through excellence in teaching. School has received its second designation as a Center of Excellence by the NLN based on the excellence of pedagogical expertise of the faculty.

\section{Discussion of findings}

Three overarching categorical themes emanate from the data analysis that aligns with the variables identified in the contingency theory conceptual framework: environment, pedagogy, and leadership. The contingency theory is guided by the general orienting hypothesis that organizations whose internal features best match the demands of their environments will achieve the best adaptation ${ }^{[28]}$. Figure 2 illustrates how the contingency theory applies to this nursing program offering online courses. The external environmental demand in this case study includes the distant education environment offering online courses in the nursing program. The design of an organization and its subsystems must 'fit' with the environment ${ }^{[28]}$. Favorable outcomes for nursing programs offering online courses are contingent upon technological environment, pedagogical competence, and leadership in a collaborative model within the distant education milieu. The institution in this case study has evidenced this contingency model.

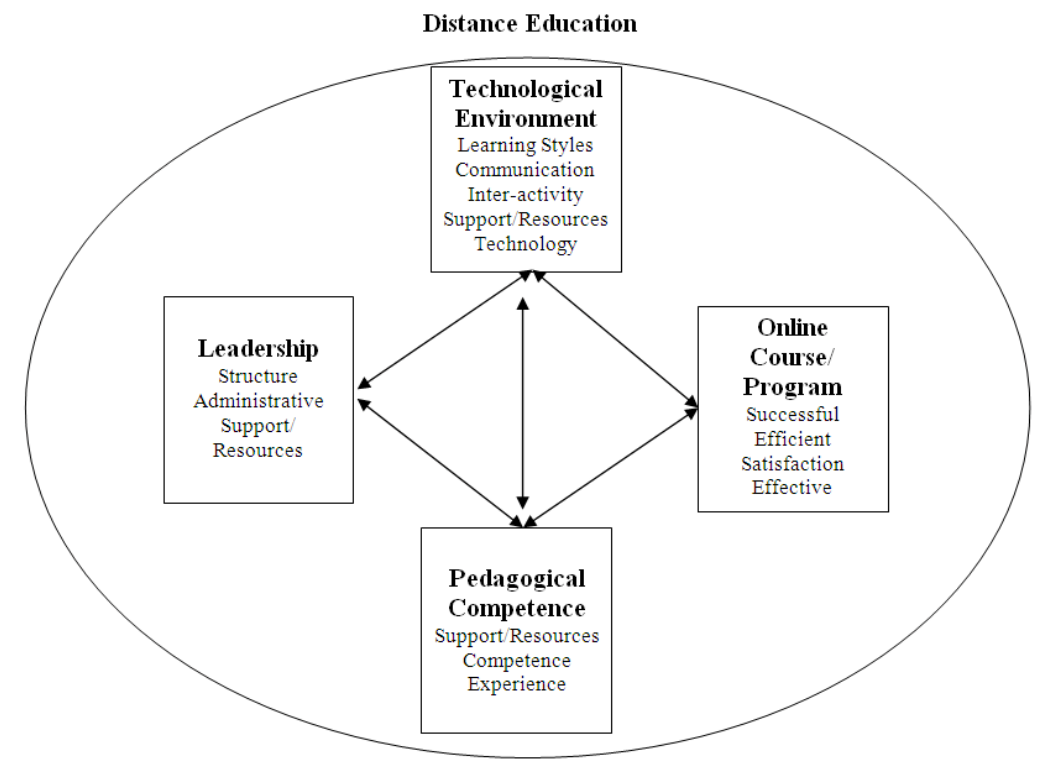

Figure 2. Contingency Theory in Nursing Programs Offering Online Courses 


\subsection{Environment and online learning}

The online nursing program serves as the external environment in this case study. According to contingency theory, changes in an environment require appropriate changes in patterns of organization to deal with that environment ${ }^{[30]}$. The participants in this study concur that the external online environmental demands involved in online learning requires resources and instructional design competence to meet the learner needs.

\subsection{Pedagogy and online environment}

Literature sustains that nurse educators must receive formalized pedagogical preparation of teaching strategies, curriculum design, technological training and evaluation frameworks supported by the organizational structures, processes, and policies of the university to address pedagogical competence ${ }^{[32]}$. The participants in this case study research reported that nursing faculty does not receive specialized or required formal training in online course development. These findings raise concerns because according to the contingency theory, when distance education programs add to existing systems without changing subsystems, quality may be compromised.

Plausible rival explanations may include that experience in teaching and mentoring provides the necessary skills for online pedagogical competence. However, the stakeholders and gatekeepers of the academic staff in higher education are pivotal in defining pedagogical competence as well as demanding development of that competence in online teaching and learning. Contingency theory upholds that effective leaders must meet the demands imposed by the situation and assure the resources exist to validate pedagogical competence in the program.

\subsection{Leadership and online environment}

Participants stress the importance of distinguishing that online learning involves technology, pedagogical skills, and competence. Institutional leadership has balanced these demands and developed sound strategic changes. The academic and experiential preparation of faculty meets the diverse needs of the institution and its Mission. The leaders of this program have pedagogically competent faculty members with the necessary skills to teach online as demonstrated in the findings.

Although this case research study revealed that this program does not structure the NLN Educator Core Competencies and iNACOL National Standards into their online programs, the findings revealed that the program does employ a learnercentered approach requiring the faculty to facilitate knowledge through guidance to the pursuit of knowledge using technology. The program does use the Chickering and Gamson's Seven Principles of Good Practice ${ }^{[33]}$ as the program framework. While these principles provide a framework; they do not offer standardized competencies to measure pedagogical skills necessary for teaching in the online environment. However, the principles of good practice, graphic design principles, communication, class content, teaching strategies, and grading do mimic the NLN and iNACOL competencies which demonstrate internal consistency among the described frameworks.

\subsection{Contingency leadership theory}

The Contingency Leadership Theory upholds that: 1) the design of an organization and its subsystems must 'fit' with the environment, and 2) effective leaders not only have a proper 'fit' with the environment but also between its subsystems ${ }^{[28]}$. The leadership at this institution has structured a framework integrating an abundance of support and resources in technology and pedagogical subsystems to 'fit' within the distant education environment. Leadership does not only 'fit' within this environment, but demonstrates effective collaboration between the subsystems. For example, the nursing program in this case study integrates a team approach to design and develop the online courses. Each team in this program consists of an instructional designer with instructional technology background assigned to each faculty content expert member. O'Neil, Fisher, and Newbold ${ }^{[34]}$ maintain that the integrated team model should consist of content experts, instructional designers, information technology support, and administrative support. Without instructional design and technological skills, essential elements may be overlooked and may result in not achieving the desired learning outcomes. 
Rather than create multiple subspecialty units within the distant education program, this institution demonstrates leadership by working together as a team to develop and implement online courses in a successful distant education nursing program.

\section{Limitations of the study}

A few limitations existed in this study. Due to time constrictions, only two interviews were conducted to draw conclusions. The findings cannot be transferred to other settings due to the study design. Additional interviews may have added richness to the internal validity of the study. Limitations also existed with the pre-interview assessment survey such as potential participant bias involved with self-rating tools and participant's willingness to share or fully disclose information. Participants may not have been willing to fully disclose information about the leadership or faculty during the telephone interview for concern of retribution. Additional bias may have occurred because the researcher chose the selected standards from the literature and the survey did not encompass all the national standards. Furthermore, no reliability or validity of the survey was completed.

\section{I mplications for nursing education}

Previous studies have examined components of online programs such as: inadequate technological training, preparation, instructional design, resources, skills, administrative support ${ }^{[16,35-39]}$ along with increased workloads ${ }^{[40-42]}$ for online learning. However, previous studies have not examined how nursing leaders integrate national pedagogical standards into their nursing programs. This case study adds to the body of knowledge in understanding how one leader addressed pedagogical competence in a nursing program offering online education.

Nursing administrative leaders hold great potential to shape their online programs with pedagogically competent faculty, resources, and support. Developing policies, creating infrastructure, defining faculty roles, partnering with technology experts, and understanding the elements of pedagogical competence experiences in online programs provides institutions valuable insights for designing and/or redesigning their online programs. The findings of this case study research contribute to the growing body of knowledge related to faculty in online nursing education in terms of preparation, support, resources, and leadership when developing online programs by:

- securing administrative support and infrastructure,

- evaluating the mission and vision of the institution and department,

- adding technological design training during faculty orientation,

- requiring faculty participation in the offered developmental resources not only for tenure and promotion purpose, but also for annual evaluations,

- co-teaching with an experienced online faculty member the first time teaching an online course,

- setting departmental goals for faculty member CNE, and

- implementing policies to hire faculty with MSN and/or PhD educational preparation or post-masters/doctorate certificate in nursing education.

Suggestions for further research include exploring how instructional design skills can be integrated into course development process. Replicating this study across the identified NLN Schools of Excellence would allow for additional insights to analyze how nursing programs address these themes in their online nursing programs. Exploring how other higher education disciplines address these themes will enable further discovery as to whether or not this is a limited or global phenomena. Future research on the complex themes should include more longitudinal studies examining the impact of pedagogical preparation and the possible connections between pedagogical preparation and program outcomes. 


\section{Conclusions}

Online education in nursing has progressed in the past decade and become integral in most higher education institutions. Although many nursing programs offer online courses, knowledge about the specifics of pedagogical competence related to the national standards has predominately remained within the confines of the individual institutions. This case study research upholds that successful distant education nursing programs are contingent on three variables: technological environment, pedagogical competence, and leadership in a collaborative model. The findings gained from this study may help nursing programs develop and analyze infrastructure prior to online learning in terms of pedagogical competence and leadership roles. This in turn may sustain long-term vitality in online nursing programs.

\section{Acknowledgements}

I would like to acknowledge Dr. Teresa Shellenbarger for her guidance and comments in case study research in the development of this manuscript.

\section{References}

[1] Ryan M, Hodson-Carlton K, Ali NS. Reflections on the role of faculty in distance learning and changing pedagogies. Nursing Education Perspectives, 2004; 25(2): 73-80. PMid:15124511

[2] Elkind EC. Nursing faculty’s training in instructional design for online course development. (Doctoral Dissertation). 2008; Retrieved from ProQuest Dissertations and Theses (UMI 3315956).

[3] United States Department of Education. Preparing and credentialing the nation's teachers: The secretary's eight report on teacher quality based on data proved for 2008, 2009, 2010 [Internet]. 2011. Available from: http://www.ed.gov/about/reports/annual/teachprep/2011-title2report.pdf (12 December 2012 date last accessed).

[4] Schulte M. Faculty perceptions of technology distance education transactions: Qualitative outcomes to inform teaching Practices [Internet]. Journal of Educators Online, 2010; 7(2). Available from: http://www.thejeo.com/Archives/Volume7Number2/Schultepaper.pdf (11 November 2012 date last accessed).

[5] Hanford KJ. Survey current academic practices of full-time post-licensure nursing faculty who teach online. (Doctoral dissertation). 2010; Retrieved from ProQuest Dissertations and Theses. (ATT 3415669).

[6] Mancuso J. Perceptions of distance education among nursing faculty members in North America. Nursing \& Health Sciences, 2009; 11(2): 194-205. PMid:19519708 http://dx.doi.org/10.1111/j.1442-2018.2009.00456.x

[7] Bennett P. Confronting competency. The Safety \& Health Practitioner, 2010; 28(2): 49.

[8] National League of Nursing. Core competencies of nurse educators with task statements [Internet]. 2005. Available from: http://www.nln.org/facultydevelopment/pdf/corecompetencies.pdf (31 October 2012 date last accessed).

[9] James ML. Middle school teachers' understanding of technology integration. (Doctoral dissertation). 2009; Retrieved from ProQuest Dissertations and Theses. (ATT 3387974).

[10] Carr T. An examination of leadership styles in implementing instructional technology: A case study to examine the elementary school principle perspective. (Doctoral Dissertation). 2010; Retrieved from ProQuest Dissertations and Theses (ATT 3475759).

[11] Richey RC, Fields DC, Foxon M. Instructional design competencies: The standards (3rded.). Syracuse, NY: ERIC Clearinghouse on Information \& Technology. 2001.

[12] Oblinger DG, Hawkins BL. The myth about online course development [Internet]. EDUCAUSE Review, 2006; 41(1): 14-15. Available from: http://net.educause.edu/ir/library/pdf/erm0617.pdf (31 October 2012 date last accessed).

[13] Macy RA. A collective case study: The transitional experiences of nursing faculty making the changeover from teaching face-toface to teaching nursing course online. (Doctoral dissertation). 2006; Retrieved from ProQuest Dissertations and Theses. (ATT 3235448).

[14] Moore GA. Online pre-licensure nursing BSN programs: A study of faculty perceptions. (Doctoral dissertation). 2007; Retrieved from ProQuest Dissertations and Theses. (ATT 3240022).

[15] Lorenzetti J. The ABCs of faculty certification for online teaching and development. Distance Education Report, 2008; 12(8): 3-6.

[16] Haber J, Mills M. Perceptions of barriers concerning effective online teaching and policies: Florida Community College faculty. Community College Journal of Research \& Practice, 2008; 32(4-6): 266-283. http://dx.doi.org/10.1080/10668920701884505

[17] Lara S, Whittier D. Preparing teachers, student teachers, and schools for the 21st century: Review of recent reports in the US. 2004; Paper presented at the World Conference on Educational Multimedia, Hypermedia and Telecommunications (EDMEDIA), Lugano: Switzerland.

[18] Johnson A. A nursing faculty’s transition to teaching online. Nursing Education Perspectives. 2008; 29(1): 17-22. PMid:18330417 
[19] National Council for Accreditation of Teacher Education. Professional standards for the accreditation of teacher preparations institutions [Internet]. 2008; Available from: http://ncate.org/LinkClick.aspx?fileticket=nX43fwKc4Ak\%3d\&tabid=474 (11 November 2012 date last accessed).

[20] American Association of Colleges of Nursing. White paper: Faculty shortages in baccalaureate and graduate nursing programs: Scope of the problem and strategies for expanding the supply [Internet]. 2005. Available from:

http://www.aacn.nche.edu/Publications/pdf/05FacShortage.pdf

[21] Institutes of Medicine. The future of nursing: Focus on education [Internet]. (Report Brief) 2010; Available from: http://www.iom.edu/ /media/Files/Report\%20Files/2010/The-Future-of-Nursing/Nursing\%20Education\%202010\%20Brief.pdf

[22] Pape L, Wicks M, International Association for K-12 Online L. National standards for quality online programs [Internet]. International Association for K-12 Online Learning, 2009; Available from

[23] http://www.inacol.org/research/nationalstandards/NACOL\%20Standards\%20Quality\%20Online\%20Programs.pdf

[24] Mancuso-Murphy J. Distance education in nursing: An integrated review of online nursing students' experiences with technology-delivered instruction. Journal of Nursing Education, 2007; 46(6): 252-260. PMid:17580737

[25] Ragan L. Defining competencies for online teaching success. Distance Education Report, 2009; 13(19): 3-6.

[26] Allen IE, Seaman J. Growing by degrees: Online education in the United States [Internet]. 2005; Available from: http://www3.babson.edu/ESHIP/upload/Growing\%20by\%20Degrees.pdf

[27] Meyer JD. Administrative support for online teaching faculty. (Doctoral dissertation). 2009; Retrieved from ProQuest Dissertations and Theses. (ATT 3341929).

[28] Runyon NA. The motivation of online adjunct faculty. (Doctoral dissertation). 2008; Retrieved from ProQuest Dissertations and Theses. (ATT 3290904).

[29] Fiedler FE. A contingency model of leadership effectiveness: Advances in experimental social psychology (Vol.1). New York, NY: Academic Press. 1964.

[30] Saha SK. Contingency theories of leadership: A study. Human Relations, 1979; 32(4): 313- 323. http://dx.doi.org/10.1177/001872677903200404

[31] Derr CB, Gabarro JJ. An organizational contingency theory for education. Education Administration Quarterly, 1972; 8(2): 26-43. http://dx.doi.org/10.1177/0013161X7200800203

[32] Yin RK. Case study research: Design and methods (4th ed.). Thousand Oaks, CA: Sage. 2009.

[33] Madhavaram S, Laverie DA. Developing pedagogical competence: Issues and implications for marketing education. Journal of Marketing Education, 2010; 32(2): 197-213. http://dx.doi.org/10.1177/0273475309360162

[34] Chickering AW, Gamson ZF. Applying the seven principles for good practice in undergraduate education: New directions for teaching and learning. San Francisco, CA: Jossey-Bass Inc. 1991.

[35] O’Neil, CA, Fisher CA, Newbold SK. Developing an online course: Best practices for nurse educators. New York, NY: Springer. 2004.

[36] Fehn MJ. An exploratory case study: Faculty perceptions of the barriers and obstacles to integrating web-based instruction into the associate degree nursing program. (Doctoral dissertation). 2005; Retrieved from ProQuest Dissertations and Theses. (ATT 3179068).

[37] Johnson AE. Transition to online learning: The study of a graduate nursing faculty. (Doctoral dissertation). 2005; Retrieved from ProQuest Dissertations and Theses. (ATT 3178470).

[38] Lammers D. Faculty lived experiences in the design and development of online courses within a college of medicine: A phenomenological study. (Doctoral dissertation). 2011; Retrieved from ProQuest Dissertations and Theses. (ATT 3457280)

[39] Nguyen D, Zierler B, Nguyen H. A survey of nursing faculty needs for training in the use of new technologies for education and practice. Journal of Nursing Education, 2011; 50(4): 181-189. PMid:21117532 http://dx.doi.org/10.3928/01484834-20101130-06

[40] Telmesani M. Faculty's perceptions of online education: A qualitative study. (Doctoral dissertation). 2010; Retrieved from ProQuest Dissertations and Theses. (ATT MR69696)

[41] Judge S, O’Bannon B. Faculty integration of technology in teacher preparation: Outcomes of a development model. Technology, Pedagogy, and Education, 2008; 17(1): 17-28. http://dx.doi.org/10.1080/14759390701847435

[42] Orr R, Williams MR, Pennington K. Institutional efforts to support faculty in online teaching. Innovative Higher Education, 2009; 34(4): 257-268. http://dx.doi.org/10.1007/s10755-009-9111-6

[43] Taylor A, McQuiggan C. Faculty development programming: If we build it, will they come? EDUCAUSE Quarterly, 2008; 31(3): $28-37$. 